補経誌, J Jpn Prosthodont Soc, 32 : 1063 1066, 1988.

原著論文

\title{
画像解析システムの歯科補綴学への応用 一顔および中切歯の計測-
}

佐藤 吉則 大木 一三 木村 一之*

\section{Application of an Image Analyzing System on Prosthodontics}

- Measurements of Human Profiles of Face and Central Incisor tooth -

\author{
Yoshinori Satoh, Katsuzo Ohki and Kazuyuki Kimura*
}

\begin{abstract}
The profiles of face and central incisor tooth surface are known to be similar. This study evaluated the accuracy of an image analyzing device and quantitatively analyzed the face and tooth profiles.

The device consisted of a CCD camera, Shade Corrector, Video recorder, Image Analyzer (LA500, PIAS Co.) and a microcomputer (PC-9801 VX 2, NEC Co.).

Squares $(150 \times 150 \mathrm{~mm}$ and $10 \times 10 \mathrm{~mm}$ ) and a metal coin (diameter $20 \mathrm{~mm}$ ) were used for evaluation of the system ability. The procedure for the measurement were $: 1$ ) the squares and the coin were measured to obtain values for areas and perimeter lengths, and 2) study models of 6 volunteers, 1 female and 5 males, between the age of 25 and 30 , were taken measurement on their face and tooth profiles.

The average error rate was less than $5 \%$ on the squares and coin. The average ratios of the long axes of face and tooth was $1 / 19$, the short axes $1 / 16$.
\end{abstract}

Key words : image analyzing system, human face profile, central incisor tooth profile

\section{I. 緒言}

床用前崡部人工歯の形態および大きさは，有床補緅物 の審美性に影響する因子である11. この前歯部人工歯の 大きさを選択する方法として, 補緅臨床上, 顔の長幅径

日本大学歯学部補緅学教室局部床義歯学講座（主任：大木一 三教授)

* 日本大学齿学部放射線学教室 (主任 : 西連寺永康教授) The Department of Removable Partial Denture Prosthodontics, Nihon University School of Dentistry (Chairman : Prof. Katsuzo Ohki)

* The Department of Radiology Nihon University School of Dentistry (Chairman : Prof. Eiko Sairenji) 昭和 63 年 3 月 23 日受付
から人工歯の大きさを選択する方法 ${ }^{2,3)}$ を用いることが ある.

顔と曾との大きさについての関連性は, 従来, 直接計 測法 $^{4)}$, 写真計測法 ${ }^{5 ~ 9)}$, トレース法 ${ }^{10)}$ およびX線 写真 法11)などによって計測されている. しかし，審美的な有 床補緅物を調製するためには，顔，歯および人工歯の形 態および大きさに関する詳細な計測が必要である.

そこで著者らは，これらの被験体を計測するため，産 業界や医学をはじめ, 歯科材料学 ${ }^{12,13)}$, 歯科放射線学 ${ }^{14)}$,

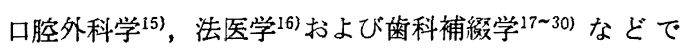
利用されている画像解析装置とその周辺器機とを導入す ることを試みた. 今回は，この画像解析システムについ て，その精度を測定検討し，併せて被験者について，そ 
110-1064

の顔および中切歯の長幅径をそれぞれ計測し，人工歯選 択の一方法としてその有効性を検討した.

\section{II. 実験方法}

\section{1. 画像解析システムの概要}

本システムは，入力装置として $\mathrm{CCD}$ テレビカメラ (PIAS 社 PX-370, 画素数 H 512×V 512), 被験体の輝度 ムラを修正するシェーディング・コレクター (PIAS 社 PS-9), 画像録画のためのビデオテープレコーダー（National 社 AG-6300), 画像処理装置 (PIAS 社 LA-500), RGB モニターカラーテレビ (SONY 社 KV-14 MD 1), パーソナルコンピューター (NEC 社 PC-9801 VX 2), デジタイザー (WACOM 社 WT-460 M) およびプリン ター (SHARP 社 IO-725) より構成されている（図 1, 2).

\section{2. 画像解析システムの精度測定}

1) 試料

精度測定には, 円形として直径 $20 \mathrm{~mm}$ の 1 円玉と, 四角形として製図用グラフ用紙に書いた $10 \times 10 \mathrm{~mm}$ お よび $150 \times 150 \mathrm{~mm}$ の正方形との, 計 3 つの形態を試料 として用いた。

2) 画像入力

CCD テレビカメラは, カメラスタンドに固定し, カ メラと被験体との距離は, 直径 $20 \mathrm{~mm}$ の円形および $10 \times 10 \mathrm{~mm}$ の四角形入力時には $15 \mathrm{~cm}, 150 \times 150 \mathrm{~mm}$ の 四角形入力時には $50 \mathrm{~cm}$ にそれぞれ離し, 白色蛍光灯室 内照明下で入力した.

入力については, 256 階調で擬似カラー化させた画 像 をモニターテレビに映し出し, 画像の輝度ムラをシェー ディング・コレクターで可及的に一定となるよう修正し たのち, 画像処理装置のフレーム・メモリーおよびディ スクに原画像として入力した.

3) 画像処理

画像処理は, 以下の手順で行った.

(1) ウィンドウ処理

(2) ヒストグラム

(3) 2 值化

4) 画像計測

計測は， 2 値化された 3 つの形態の被験画像につい て，それぞれの周囲長および面積を計測し，それぞれの 值を理論值々比較して, 本システムの誤差を求めた.

32 巻 5 号 (1988)

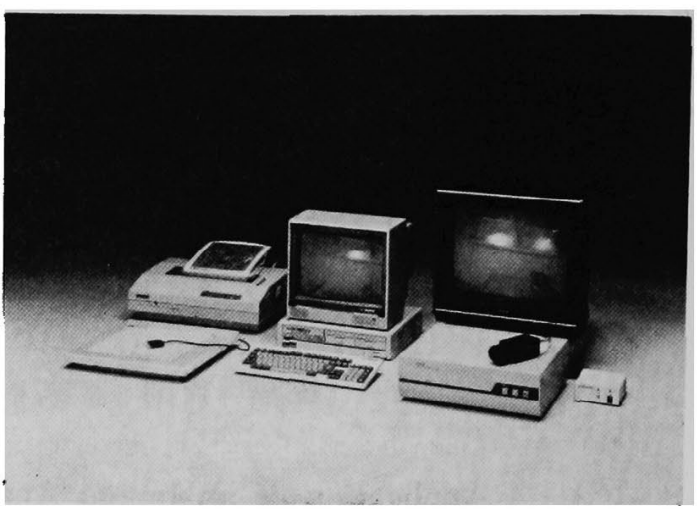

図 1 画像解析システム

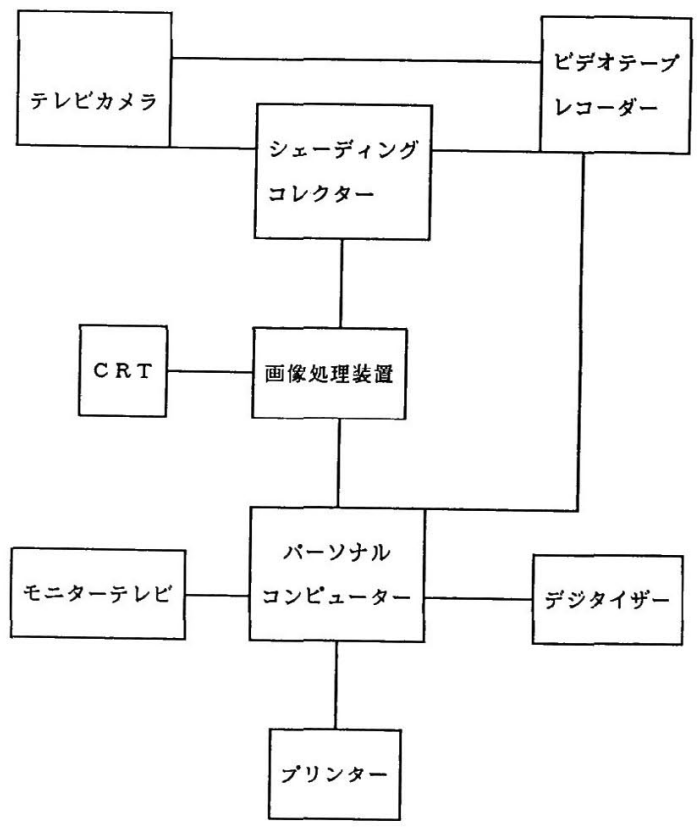

図 2 画像解析システムのプロック図

3. 顔および中切歯の計測

1) 被験者

被験者は，上䫑左側または右側のどちらか一側，ある いは両側の中切歯が補綴修復処置されていない者で, 20 歳代の男性 5 名, 女性 1 名の計 6 名である.

2) 顔の画像入力

顔の画像は，まず被験者を歯科治療用ニニットの椅子 に座らせ, 咬合平面が床面と平行となるよう安頭台を固 定した. 次いで, テレビカメラを被験者の顔と同一の高 さとなるように固定し，カメラレンズと顔とは $150 \mathrm{~cm}$ 離し, 白色虽光灯室内照明下で入力した. 
表 1 画像解析システムの精度測定

\begin{tabular}{|c|c|c|c|c|c|c|}
\hline & \multicolumn{3}{|c|}{ 物体の周囲長 $(\mathrm{mm})$} & \multicolumn{3}{|c|}{ 物体の面積 $\left(\mathrm{mm}^{2}\right)$} \\
\hline & 理論値 & $\begin{array}{c}\text { 平 均 } \\
\text { (標準偏差) }\end{array}$ & 誤差 (\%) & 理諭值 & $\begin{array}{c}\text { 平 均 } \\
\text { (標準偏差) }\end{array}$ & 嵒差 $(\%)$ \\
\hline $\begin{array}{l}\text { 正方形 } \\
(150 \times 150 \mathrm{~mm})\end{array}$ & 600.0 & $\begin{array}{c}609.8 \\
(6.0)\end{array}$ & 2 & 22500.0 & $\begin{array}{r}22727.9 \\
(150.9)\end{array}$ & 1 \\
\hline $\begin{array}{l}\text { 正方形 } \\
(10 \times 10 \mathrm{~mm})\end{array}$ & 40.0 & $\begin{array}{l}41.4 \\
(0.3)\end{array}$ & 3 & 100.0 & $\begin{array}{c}103.7 \\
(0.7)\end{array}$ & 4 \\
\hline $\begin{array}{l}\text { 由 形 } \\
\text { (直径 : } 20 \mathrm{~mm} \text { ) }\end{array}$ & 62.8 & $\begin{array}{l}65.2 \\
(0.3)\end{array}$ & 4 & 314.0 & $\begin{array}{l}309.4 \\
(1.8)\end{array}$ & 2 \\
\hline
\end{tabular}

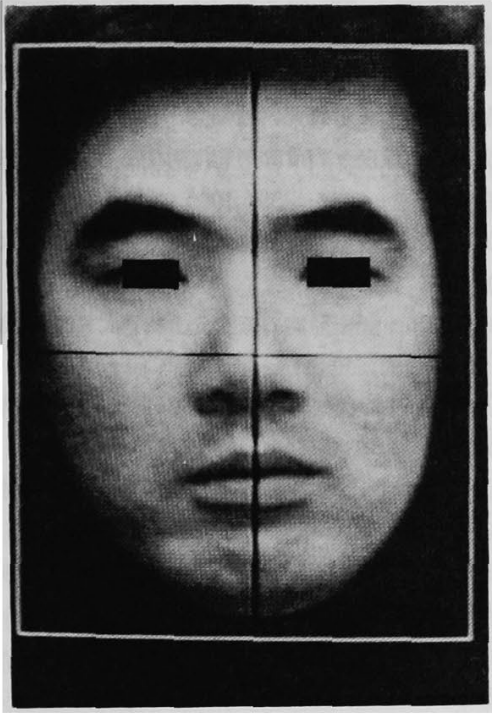

図 3 顔の長幅径の設定

\section{3） 中切歯の画像入力}

中切歯の画像は, 口腔内の歯をカメラで直接入力する 方法を試みたが, 各歯の輪郭形状を鮮明に入力寸ること が困難であった. そこで，この形態の画像入力のため， まず被験者の口腔内歯列をアルジネート印象材で概形印 象し，硬質石こう模型を作製した. 次いで，この模型の 健全な左側または右側中切歯を被験歯として選び，黒色 のリキテックス絵具を用いて当該歯の両隣在歯および歯 頸部を約 $2 \mathrm{~cm}$ の幅でふち取りした。これにより，被験 歯の輪郭形状は明確となり，それによって画像処理が容 易となった.

画像入力は, カメラレンズと硬質石こうの被験歯唇側 面とを $15 \mathrm{~cm}$ 離し, 白色蛍光灯照明下で行った.

4）顔および中切歯の長幅径

顔の長径は，鼻唇溝を通るオトガイ最下点と頭髪の生 え際とを結んだ直線, 幅径は左右煩側弓部最突出点とを 結んだ直線として設定した（図3).

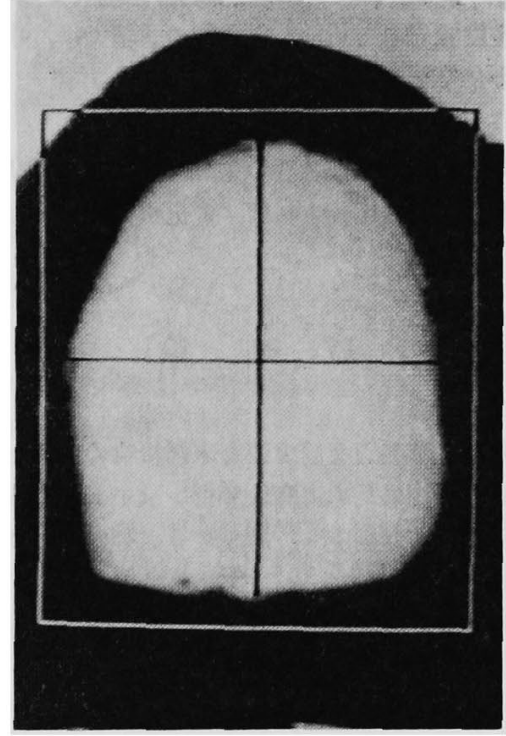

図 4 中切歯の長幅径の設定

中切歯の長径は, 歯頸部最突出点と切端とを結んだ直 線, 幅径は近遠心的最突出点を結んだ直線として設定し た(図 4).

\section{III. 結果および検討}

\section{1. 画像解析システムの精度測定}

本システムの精度測定は，3つの形態の周囲長および 面積について計測した結果, $5 \%$ 以内であった（表 1 ).

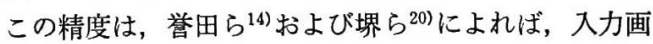
像の大きさによって影響されると報告されている. した がって, 試料が小さい場合は, 可及的に大きい画像とし て入力すれば， 1 画素あたりの原画像に対する比率が小 さくなり，精度はさらに向上するものと考えられる. 
表 2 画像解析による顔面と歯冠の長幅径

\begin{tabular}{|c|c|c|c|}
\hline & & 长 径 & 煯 径 \\
\hline 顔 & 測定値の斗均 & 205.3 & 149.9 \\
\hline$(\mathrm{mm})$ & 測定値の锗準作㫱 & 7.3 & 8.9 \\
\hline & 測定値の斗均値 & 11.0 & 9.4 \\
\hline$(\mathrm{mm})$ & 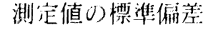 & 1.4 & 0.5 \\
\hline 柬：顔 & & $1 / 19$ & $1 / 16$ \\
\hline
\end{tabular}

\section{2. 顔および中切歯の長幅径}

両形態の長幅径掞よび両者の長さの比率は, 表 2 に示 した. 被験者 6 名を用いた著者らの成績では，中切歯の

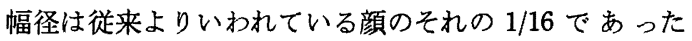
が，長径は1/19であった。

これらの比率は, 被験者の数を増し, 顔および中切歯 の形態を分類して比較すれば，変化するのではないかと 考える.

\section{IV. 結 論}

著者らは，審美的な前歯部有床補緅物の調製を目的と して, 画像計測のために画像解析システムを導入し, こ のシステムの精度測定と, 被験者 6 名の顔および中切歯 の長幅径の計測とを行い, 以下の結論を得た.

1. 画像解析システムの精度は, その誤差が $5 \%$ 以内 であり，画像解析に十分有効であると考える.

2. 中切歯の長幅径は， 6 名の計測によれば, 顔の長 径の $1 / 19$ であり, 顔の幅径の $1 / 16$ であった.

本研究は, 昭和 62 年度日本大学歯学部佐藤研究費によるもの であり, 本論文の要旨は第 35 回 JADR 総会 (昭和 62 年 12 月, 鶴見)において発表した。

\section{文献}

1) Lombardi, R.E.: The principles of visual perception and their clinical application to denture esthetics, $\mathrm{J}$ Prosthet Dent, $29: 358 \sim 382,1973$.

2）坪根政治, 豊田静夫：総義菊臨床形態学，288 293, 医歯 薬出版, 東京, 1982 .
32 巻 5 号 $(1988)$

3）林都志夫，平沼前二，根本一男，松本值之，山縣健佑，長

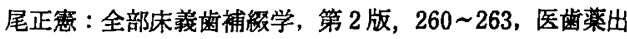
版, 東京, 1987 .

4）杉浦英二，佐々間弘侮，根本一男，北条 尚：上歌中切齿 の唇面形態に関する研究，口病誌，26:629 633, 1959.

5) Williams, J.L. : The Esthetic and anatomical basis of dental prosthesis, Dent Cosm, $53: 1 \sim 26,1911$.

6) Williams, J.L. : A New classiflcation of human tooth forms with special reference to A new system of artificial teeth, J Allied Dent Soc, $9: 1 \sim 52,1914$.

7）恩田稔彦：人の颜の形と歯列弓の形及び歯冠の形との相互 類似性に関する研究，菌科学報, $62: 194 \sim 208,1962$.

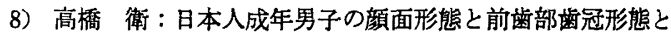
の関連性仪関する研究，補緅誌，11：167 180，1967.

9）石島 勉 : 顔面と前歯部形態に対する 2 重撮影法の検㷉, 要院大誌, $24: 264 \sim 280,1986$.

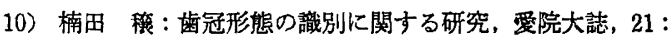
$170 \sim 191,1983$.

11）中原リザ子 : 顔面形態の三次元分析法に関する検吋, 歯学, $71: 247 \sim 253,1983$.

12）小山真美子：画像処理装置化上る鉡巣分布の定量的解析， 歯材器誌, $2: 634 \sim 644,1983$.

13）田辺直紀 : パーソナル画像解析システムの歯科材料研究へ の応用, 日大歯学, $59: 596 \sim 601,1985$.

14）誉田栄一, 土門正治, 中村 正：X線像自動画像解析装置 の測定精度，歯放線，23:252 255, 1984.

15）夏目長門, 河合 幹 : Automatic Image Analyser System を使用した筋組織の定量化に対する試み，愛院大誌，22： 320 327, 1984.

16）印南知弘：歯痕の研究, 日本法医誌， $41: 247 \sim 262,1987$.

17）小林賢一，内田博之，鈴木哲也，水口俊介，田中慎二，長 尾正憲，加藤二久：マイクロコンピューターによる超音波 画像処理システムの開発, 補敘誌, 31:1099 1103, 1987.

18）加藤光雄, 斉藤光彦, 幸阪保雄, 後藤忠正, 藍 稳: 咀嚼 機能の評価方法について，補緅誌，31：1506 1513, 1987.

19）土佐淳一, 田中昌博, 村田洋一, 藏英, 上田直克, 川 添堯枇: 咬合接触像のビジュアル化, 補緅誌, $31 ： 1553$ $1557,1987$.

20）堺 諴，山内六男，川野衰二：画像解析装置を用いた印象 材の内部気泡測定に関する研究, 補緅誌, $32: 28 \sim 36$, 1988. 